\title{
PENGEMBANGAN PERANGKAT PEMBELAJARAN KOOPERATIF TIPE THINK PAIR SHARE DENGAN MENGGUNAKAN TEKNIK MIND MAP PADA MATA PELAJARAN PKN DI KELAS IV SEKOLAH DASAR
}

\author{
${ }^{1}$ Ary Mustrifarini, ${ }^{2}$ Mustaji, Waspodo Tjipto Subroto \\ ${ }^{1}$ Mahasiswa Program Pascasarjana, Prodi Pendidikan Dasar, Universitas Negeri Surabaya, \\ ${ }^{2 \& 3}$ Dosen Pascasarjana, Prodi Pendidikan Dasar, Universitas Negeri Surabaya \\ e-mail: arymust@yahoo.com
}

\section{Received： Juli 2017}

Reviewed: Agustus 2017

Accepted : September 2017

Published : September 2017

\section{ABSTRACT}

This research is aimed to describe the feasibility, practicity, and effectiveness of the development of learning cooperative equipment type think pair share by using mind mapp technique of civic lesson for the Fourth Grade Students Elementary School. In this research, the learning equipment that is developed : Lesson Plan, Student Worksheet, and Test. This research uses theory of the development of 4-D models of Thiagarajan (1974) consisting of four stages: (a) define, (b) design, (c) develop and (d) disseminate. But the disseminate is not did because of the limitation of finance, energy, time, and experience and the result of research is only done at SD Muhammadiyah Madiun city as the place of the research. The research is only until develop step to 0,99 in the category of goodof learning isn 99,7\%, this means that teachers can implement the learning in conformity with the pla. Moeover, it is also practical based on research that shows $97,1 \%$ the student actively in learning, give positive response and unterested in participating in learning as much as $100 \%$, and the result of Achievment Test is 93,8\% due KKM. Baed on the analysis above, it can be concluded that the type cooperative learning Think Pair Share at Civic Lesson on the fourth grade of Elementary School is feasible, practical, and effective to use, but it still require an adjustment to the situation and condition of each school.

Keywords: Kit Media, Science Learning, Scientific, dan Mastery of Concept.

\section{ABSTRAK}

Penelitian ini bertujuan mendeskripsikan kelayakan, kepraktisan, dan keefektifan pengembangan perangkat pembelajaran kooperatif tipe think pair share dengan menggunakan teknik mind map pada mata pelajaran PKn di kelas IV Sekolah Dasar. Dalam penelitian ini, perangkat pembelajaran yang dikembangkan antara lain : Rencana Pelaksanaan Pembelajaran (RPP), Lembar Kerja Siswa (LKS), dan Tes Hasil Belajar (THB). Tahap-tahap penelitian pengembangan perangkat pembelajaran ini menggunakan model 4-D (four-d model) dari Thiagarajan, Semmei dan Semmel (1975). Model 4-D terdiri dari tahap pendefinisian (define), tahap perancangan (design), tahap pengembangan (develop), dan tahap penyebaran (disseminate). Dikarenakan keterbatasan biaya, tenaga, waktu dan kesempatan maka pendesiminasian tidak dilakukan. Hasil penelitian hanya diterapkan di tempat penelitian, yaitu di SD Muhammadiyah Kota Madiun. Maka dalam rancangan penelitian ini, pengembangan perangkat pembelajaran hanya sampai pada tahap ketiga yaitu tahap pengembangan (develop). Data hasil penelitian diperoleh sebagai berikut: keseluruhan validasi diperoleh rata-rata skor 3,55 dengan realibilitas 0,99 dalam kategori baik, pembelajaran ini juga praktis berdasarkan keterlaksanaan pembelajaran sebesar 99,7\% ini artinya guru dapat melaksanakan pembelajaran sesuia dengan rencana. Selain itu, perangkat pembelajaran ini juga praktis berdasarkan hasil penelitian yang menunjukkan 97,1\% siswa aktif dalam pembelajaran, respon positif siswa dan berminat mengikuti pembelajaran seperti sebesar 100\%, dan hasil THB 93,8\% tuntas mencapai KKM. Berdasarkan hasil 
analisa diatas, dapat disimpulkan bahwa perangkat pembelajaran kooperatif tipe Think Pair Share layak, praktis, dan efektif untuk digunakan, namun masih memerlukan penyesuaian dengan situasi dan kondisi di sekolah masing-masing.

Kata Kunci: Pengembangan perangkat, pembelajaran kooperatif, pembelajaran kooperatif tipe think pair share, teknik mind map.

\section{PENDAHULUAN}

Hasil belajar siswa pada mata pelajaran PKn tidak sesuai dengan harapan atau belum mencapai Kriteria Ketuntasan Minimal (KKM). Hal ini disebabkan karena pembelajarannya di Sekolah Dasar pada umumnya masih bersifat konvensional. Selain itu, ada materi-materi tertentu yang dianggap sulit dan hasil belajar yang dicapai Hal ini juga terjadi di SD Muhammadiyah Kota Madiun. Salah satunya adalah materi tentang globalisasi. Selain materi ini masih asing bagi siswa, model pembelajaran yang dilakukan guru juga kurang menarik. Guru hanya menjelaskan (ceramah) tentang materi globalisasi, membagikan ringkasan materi, kemudian mengerjakan worksheet//LKS (penugasan). Pada pembelajaran tersebut guru juga tidak menggunakan media. Jadi, ringkasan materi dan guru sebagai sumber informasi dan siswa hanya bersifat pasif dan individu. Bahkan pembelajaran tersebut juga tidak didukung dengan perangkat pembelajaran yang baik, sehingga pembelajaran kurang bermakna bagi siswa.

Pada dasarnya aktivitas siswa dalam pembelajaran PKn seharusnya tidak tergantung pada guru saja, tetapi sebaiknya guru memberikan ruang dan waktu agar siswa dapat aktif dan kreatif seluas-luasnya dalam rangka mengembangkan bakat, minat, kemampuan, intelegensi, dan potensi-potensi lain yang dimilikinya (student centre). Selain sebagai fasilitator, guru selayaknya bertindak motivator dan inovator. Dimana guru harus selalu memberi motivasi kepada siswa dan melakukan inovasi dalam proses pembelajaran, sehingga siswa lebih tertarik dan hasil belajar yang dicapai lebih optimal.

Di SD Muhammadiyah kota Madiun, terutama di kelas atas yaitu kelas IV-VI guru PKn belum sepenuhnya memberikan motivasi dan memiliki inovasi yang bisa menarik siswa. Oleh karena itu, Guru perlu menerapkan model pembelajaran yang inovatif yang mampu menfasilitasi dalam menemukan konsep dan berinteraksi dalam pembelajaran. Salah satunya dengan mengembangkan model pembelajaran kooperatif.

Menurut Isjoni (2013: 23) pembelajaran kooperatif merupakan model pembelajaran ini telah terbukti dapat digunakan dalam berbagai mata pelajaran, termasuk PKn. Terdapat berbagai macam tipe model pembelajaran kooperatif, salah satunya adalah Tipe Think Pair Share
(TPS). Dalam proses pembelajaran Think Pair Share (TPS) pada penelitian ini, menggunakan teknik mind map sebagai alternatif teknik pembelajaran aktif yang mengikutsertakan siswa berpikir kreatif dalam pembelajaran. PKn yang identik dengan hafalan dan banyak mencatat, akan mudah dipahami dan diingat siswa dengan sendirinya melalui mind map. Siswa mengetahui inti materi, kemudian membuat peta pikirannya sesuai dengan ide-ide dan kreativitasnya sendiri-sendiri.

Mind map merupakan tehnik penyusunan catatan demi membantu siswa menggunakan seluruh potensi otak agar optimum. Dengan teknil mind map siswa dapat meningkatkan daya ingat hingga $78 \%$.

Guru sebagai perancang pembelajaran harus merancang perencanaan pembelajaran sesuai dengan kebutuhan siswanya. Dengan perencanaan yang baik, akan membuat pembelajaran terkonsep. Guru akan mendapat gambaran apa yang akan dilakukan siswa. Namun hal ini berbeda dengan kenyataaanya. Perencanaan pembelajaran dibuat oleh seorang guru tidak sebagai panduan untuk melakukan kegiatan pembelajaran dan tanpa memperhatikan kebutuhan siswa, tetapi hanya sebagai syarat administratif saja. Oleh sebab itu diperlukan adanya perangkat pembelajaran yang sesuai dengan kebutuhan siswa dengan menggunakan model dan teknik pembelajaran agar siswa nilainya mencapai KKM dan tuntas. Berdasarkan permasalahan di atas, peneliti bermaksud mengembangkan perangkat pembelajaran kooperatif tipe Think Pair Share (TPS) dengan menggunakan teknik mind map pada mata pelajaran PKn bagi di kelas IV SD, khususnya pada materi Globalisasi.

\section{KAJIAN PUSTAKA}

\section{A. Hakekat Pembelajaran PKN di Sekolah Dasar}

Dalam kurikulum KTSP, Pendidikan kewarganegaraan merupakan mata pelajaran yang memfokuskan pada pembentukkan diri yang beragam, dari segi agama, sisi budaya, bahasa, usia, dan suku bangsa yang menjadi warga negara Indonesia yang cerdas, trampil, dan berkarakter yang diamanatkan oleh Pancasila dan UUD 1945.

Berdasarkan Pemendiknas No. 22 tahun 2006 Ruang Lingkup Mata pelajaran Pendidikan Kewarganegaraan 
untuk Pendidikan Dasar dan Menengah secara umum meliputi aspek-aspek sebagai berikut:

1. Persatuan dan kesatuan bangsa meliputi: Hidup rukun dalam perbedaan, Cinta lingkungan, Kebanggaan sebagai bangsa Indonesia, Sumpah Pemuda, Keutuhan Negara Kesatuan Republik Indonesia, Partisipasi dalam pembelaan negara, Sikap positif terhadap Negara Kesatuan.

2. Norma hukum dan perturan meliputi : Tertib dalam kehidupan keluarga, Tata Tertib di sekolah, Norma yang berlaku di masyarakat, Peraturan-peraturan daerah, Norma-norma dalam kehidupan berbangsa dan bernegara, Sistem hukum dan peradilan nasional, Hukum dan peradilan Internasional.

3. Hak Asasi Manusia meliputi: Hak dan kewajiban anak, Hak dan kewajiban anggota masyarakat, Instrumen Nasional dan Internasional, HAM, Pemajuan, Penghormatan dan perlindungan HAM.

4. Kebutuhan warga negara meliputi:Hidup gorong royong, Harga diri sebagai warga masyarakat, Kebebasan berorganisasi, Kemerdekaan mengeluarkan pendapat, Menghargai keputusan bersama, Prestasi diri, Persamaan kedudukan warga negara.

5. Konstitusi Negara meliputi : Proklamasi kemerdekaan dan konstitusi yang pertama, konstitusi-konstitusi yang pernah digunakan di Indonesia, Hubungan Dasar negara dengan konstitusi.

6. Kesatuan dan Politik meliputi :Pemerintahan desa dan kecamatan, Pemerintahan daerah dan otonomi, Pemerintahan pusat, Demokrasi dan sisitem politik, Budaya politik, Budaya demokrasi menuju masyarakat madani, Sistem pemerintahan, Pers dalam masyarakat demokrasi.

7. Pancasila meliputi: Kedudukan Pancasila sebagai dasar negara dan ideologi negara, proses perumusan Pancasila sebagai dasar negara, Pengalaman nilai-nilai Pancasila dalam kehidupan sehari-hari, Pancasila sebagai ideologi terbuka.

8. Globalisasi meliputi : Globalisasi di lingkungannya, Politik luar negeri Indonesia di era globalisasi, Dampak globalisasi, Hubungan ineternasional dan oraganissasi internasional, dan mengevaluasi globalisasi.

Menurut Yamin (2011: 28) prinsip penyajian materi ajar di sekolah dasar meliputi empat tahapan, yakni:

1. Dari mudah ke sukar. Prinsip ini digunakan dalam pengajaran khususnya dalam pendidikan nilai moral dan teori-teori pendidikan. Untuk memahami hal-hal yang bersifat sukar dimulai dari yang bersifat mudah.
Jika dilihat dari prinsip perkembangan anak, cara ini sangat tepat untuk siswa sekolah dasar

2. Dari sederhana ke rumit. Prinsip ini didasarkan pada konsep atau nilai yang berkaitan dengan pengalamanpengalaman nilai-nila Pancasila dalam kehidupan sehari-hari. Jadi konsep ini dan moral termasuk dalam hal keterampilan mulai dari yang sederhana ke yang rumit. Memulai pembiasaan, latihan keteladanan yang dimulai sejak kecil, akan terbiasa dengan hal-hal yang baik masih bersifat sederhana, kemudian ditingkatkan secara bertahap ke hal-hal yang bersifat lebih rumit, kematangan usia anak di SD juga mempengaruhi, memiliki peran dalam kaitannya dengan fase perkembangan. Siswa mudah menangkap dari apa yang diamatinya/pengamatan.

3. Dari yang konkrit ke abstrak. Siswa Sekolah Dasar pada hakikatnya lebih mudah menerima hal-hal yang sifatnya kongkrit/nyata daripada yang bersifat abstrak. Guru dapat memberikan contoh-contoh sederhana yang dapat ditiru oleh siswa. Alat bantu berupa media tentunya sangat diperlukan buat mengkongkritkan sesuatu hal yang dirasakan dan diperlukan guna mempermudah penahaman siswa.

4. Dari lingkungan paling dekat ke lingkungan lebih luas. Lingkungan pendidikan yang pertama dan utama bagi anak adalah lingkungan keluarga. Dalam kelurga anak lebih banyak melakukan interaksi atau berhubungan. Namun apakah lingkungan keluarga menjadi lingkungan pertama dan utama dalam memperoleh pendidikan

Menurut Permendiknas Nomor 22 tahun 2006 tentang Standar Isi untuk satuan pendidikan dasar dan menengah adalah sebagai berikut bahwa pendidikan kewarganegaraan adalah:

1. Berpikir kritis, rasional, dan kreatif dalam menanggapi isu kewarganegaraan

2. Berpartispasi secara aktif dan bertnaggung jawab serta bertindak cerdas dalam kegiatan bermasyarakat, bergama, bernegara, serta anti korupsi.

3. Berkembang secara positif dan demokratis untuk membentuk diri berdasarkan karakter-karakter masyarakat agar hidup bersama dengan bangsa-bangsa lain.

4. Berinteraksi dengan bangsa-bangsa lain dalam percaturan dunia secara langsung dengan memanfaatkan teknologi dan komunikasi.

\section{B. Pembelajaran Kooperatif}

Dalam pengertian bahasa Indonesia, istilah Cooperatif Learning dikenal dengan nama pembelajaran 
kooperatif. Menurut Slavin (2009: 4) pembelajaran kooperatif adalah suatu model pembelajaran dimana para siswa bekerja sama dalam kelompok-kelompok kecil untuk yang saat ini banyak digunakan untuk mewujudkan kegiatan belajar mengajar yang berpusat pada siswa (student centre), terutama untuk membantu satu sama lainnya dalam mempelajari materi pembelajaran. Dalam pembelajaran ini, siswa akan duduk bersama dalam kelompok yang dua orang untuk menguasai materi yang disampaikan oleh guru.

Roger dan David Kohnson (Suprijono, 2009: 58) mengatakan bahwa tidak semua belajar kelompok bisa dianggap pembelajaran kooperatif. Ada lima unsur dalam model kooperatif yang harus diterapkan, antara lain: (1) saling ketergantungan (positive interdependent), (2) tanggung jawab perseorangan (personal responsibility), (3) interaksi promotif (face to face promotive interaction), komunikasi antar anggota (interpersonal skill), dan (5) pemrosesan kelompok (group processing).

Adanya lima unsur dalam pembelajaran kooperatif sangat tepat diterapkan dalam pendidikan. Hal ini senada dengan pendapat Johnson David W, Roger, dan Marru Beth Stanne (2000: 54) menyatakan bahwa cooperative learning is one of the most widespread and fritifull areas of theory, research and practice education. Artinya pembelajaran kooperatif merupakan pembelajaran yang memiliki banyak keberhasilan dalam riset maupun dalam pendidikan.

Jadi pembelajaran kooperatif adalah model pembelajaran yang berbasis kelompok yang memiliki saling ketergantungan positif dan tanggung jawab baik secara individu ataupun kelompok dalam memahami sesuatu sesuai dengan tujuan yang ingin dicapai. Menurut Salvin (2009: 10), antara lain: Teams Games Tournament, CIRC, dan Team Accelerated Instruction (TAI).

Pembelajaran kooperatif selanjutnya dikembangkan oleh beberapa peneliti, sehingga sekarang ini terdapat beberapa tipe. Menurut Rusman (2010: 213), ada beberapa tipe model pembelajaran kooperatif diantaranya dalah tipe STAD (Students Teams Achievment Divisons), TGT (Teams Games Tournament), Jigsaw, TPS (Think Pair Share).

Adapun langkah-langkah pembelajaran kooperatif yang dipaparkan oleh Rusman (2010: 211) adalah sebagaimana terlihat pada tabel berikut ini :
Tabel 1.

Sintaks Model Pembelajaran Kooperatif

\begin{tabular}{|c|c|}
\hline Fase & $\begin{array}{l}\text { Tingkah Laku } \\
\text { Guru }\end{array}$ \\
\hline $\begin{array}{l}\text { Menyampaikan } \\
\text { tujuan dan } \\
\text { memotivasi siswa }\end{array}$ & \begin{tabular}{lr}
\multicolumn{2}{l}{ Guru menyampaikan } \\
semua & tujuan \\
pelajaran yang ingin \\
dicapai \\
$\begin{array}{l}\text { pembelajaran } \\
\text { tersebut }\end{array}$ \\
$\begin{array}{l}\text { memotivasi } \\
\text { belajar }\end{array}$
\end{tabular} \\
\hline $\begin{array}{l}\text { Menyajikan } \\
\text { informasi }\end{array}$ & $\begin{array}{l}\text { Guru menanyakan } \\
\text { informasi kepada } \\
\text { siswa dengan jalan } \\
\text { demonstrasi } \\
\text { lewat bacaan }\end{array}$ \\
\hline $\begin{array}{l}\text { Mengorganisasikan } \\
\text { siswa ke dalam } \\
\text { kelompok bekerja } \\
\text { dan belajar }\end{array}$ & \begin{tabular}{lr} 
Guru menjelaskan \\
pada & siswa \\
bagaimana & \\
membentuk & \\
kelompok-kelompok \\
belajar & dan \\
membantu & setiap \\
kelompok & agar \\
melakukan & transisi \\
\multicolumn{2}{c}{ secara efisien }
\end{tabular} \\
\hline $\begin{array}{l}\text { Membimbing } \\
\text { kelompok bekerja } \\
\text { dan belajar }\end{array}$ & $\begin{array}{l}\text { Guru membimbing } \\
\text { kelompok-kelompok } \\
\text { belajar pada saat } \\
\text { mereka mengerjakan } \\
\text { tugas mereka }\end{array}$ \\
\hline Evaluasi & $\begin{array}{l}\text { Guru mengevaluasi } \\
\text { hasil belajar tentang } \\
\text { materi yang telah } \\
\text { dipelajari atau } \\
\text { masing-masing } \\
\text { kelompok } \\
\text { mempresentasikan } \\
\text { hasil belajarnya. }\end{array}$ \\
\hline $\begin{array}{l}\text { Memberikan } \\
\text { penghargaan }\end{array}$ & $\begin{array}{l}\text { Guru mencari cara } \\
\text { untuk menghargai } \\
\text { baik upaya maupun } \\
\text { hasil belajar individu } \\
\text { atau kelompok. }\end{array}$ \\
\hline
\end{tabular}

\section{Pembelajaran Kooperatif Tipe Think Pair Share}

Think Pair Share (TPS) merupakan teknik pembelajaran dalam pembelajaran kooperatif yang pertama kali dikembangkan oleh Frank Lyman pada tahun 1981. TPS merupakan jenis pembelajaran kooperatif yang dirancang untuk mempengaruhi pola interaksi siswa. Trianto (2007: 30) mengemukakan bahwa Model pembelajaran kooperatif Tipe Think Pair Share (TPS) 
adalah jenis pembelajaran kooperatif yang dirancang untuk mempengaruhi pola interaksi siswa.

Supriyono (2014: 91) menjelaskan langkahlangkah dalam pembelajaran kooperatif Tipe Think Pair Share (TPS) sebagai berikut.

1. "Thinking"

Pembelajaran ini diawali dengan guru mengajukan pertanyaan atau isu terkait dengan pelajaran untuk dipikirkan oleh peserta didik. Guru memberi kesempatan kepada mereka untuk memikirkan jawabannya.

\section{2. "Pairing "}

Pada tahap ini guru meminta peserta didik berpasangpasangan. Beri kesempatan kepada pasangan-pasangan itu untuk berdiskuai. Diharapkan diskusi ini dapat memperdalam makna dari jawaban yang telah dipikirkannya dengan pasangannya.

\section{3. "Sharing"}

Pada tahap ini, hasil intersubjektif di tiap-tiap pasangan hasilnya dibicarakan dengan pasangan ke seluruh kelas. Dalam kegiatan ini diharapkan terjadi tanya jawab yang mendorong pada pengonstruksian pengetahuan secara integratif. Peserta didik dapat menemukan struktur dari pengetahuan yang dipelajarinya.

Jadi model kooperatif ini terdiri dari Thinking (berpikir) : beri kesempatan siswa untuk mencari jawaban tugas secara mandiri, Pairing (berpasangan): bertukar pikiran dengan temar sebangku, dan Sharing (berbagi berdiskusi dengan pasangan lain (menjadi 4 siswa). Pendapat lain yang mendukung, Aqib (2013: 24), Think Pair Share atau berpikir berpasangan berbagi merupakan jenis pembelajaran kooperatif yang dirancang untuk mempengaruhi pola interaksi siswa. Pola interaksi siswa tersebut dilakukan me-lalui tiga tahapan yaitu berfikir (think), berpasangan (pair), dan berbagi (share). Penguasaan siswa yang dilakukan melalui tiga tahap tersebut mampu memberikan kemudahan untuk siswa menguasai materi dan pada akhirnya mampu meningkatkan prestasi belajar.

Tjokrodiharjo (dalam Triyanto 2009: 124) memaparkan langkah-langkah pembelajaran kooperatif Tipe Think Pair Share (TPS) melalui tabel di bawah ini.

Tabel 2.

Sintaks Model Pembelajaran Kooperatif Tipe Think Pair Share (TPS)

\begin{tabular}{|c|c|}
\hline Tahap & Tingkah Laku Guru \\
\hline Tahap 1 & \\
\hline menyampaikan & - Menyampaikan \\
\hline tujuan dan & pendahuluan \\
\hline mengatur siswa & $\begin{array}{l}\text { a. Motivasi } \\
\text { b. Menyampaikan tujuan }\end{array}$ \\
\hline
\end{tabular}

\begin{tabular}{|c|c|}
\hline & $\begin{array}{l}\text { dasar diskusi } \\
\text { c. Apersepsi } \\
\text { - Menjelaskan } \\
\text { diskusi }\end{array}$ \\
\hline $\begin{array}{l}\text { Tahap } 2 \\
\text { Mengarahkan } \\
\text { diskusi }\end{array}$ & $\begin{array}{l}\text { - Mengajukan pertanyaan } \\
\text { awal/ permasalahan } \\
\text { - Modelling }\end{array}$ \\
\hline $\begin{array}{l}\text { Tahap } 3 \\
\text { Menyelenggara } \\
\text { kan diskusi }\end{array}$ & $\begin{array}{l}\text { - Membimbing/mengarah } \\
\text { kan siswa dalam } \\
\text { mengerjakan LKS } \\
\text { secara mandiri (think) } \\
\text { - Membimbing/mengarah } \\
\text { kan siswa dalam } \\
\text { berpasangan(pair) } \\
\text { - Membimbing/mengarah } \\
\text { kan siswa dalam } \\
\text { berbagi (share) } \\
\text { - Menerapkan waktu } \\
\text { tunggu } \\
\text { - Membimbing kegiatan } \\
\text { siswa }\end{array}$ \\
\hline $\begin{array}{l}\text { Tahap } 4 \\
\text { Mengakhiri } \\
\text { diskusi } \\
\text { Tahap } 5\end{array}$ & Menutup diskusi \\
\hline $\begin{array}{lr}\text { Melakukan } & \text { tanya } \\
\text { jawab } & \text { singkat } \\
\text { tentang } & \text { proses } \\
\text { diskusi } & \\
\end{array}$ & $\begin{array}{l}\text { Membantu siswa } \\
\text { membuat rangkuman } \\
\text { diskusi dengan tanya } \\
\text { jawab singkat }\end{array}$ \\
\hline
\end{tabular}

Dari pendapat-pendapat diatas, dapat disimpulkan bahwa pembelajaran kooperatif tipe Think Pair Share (TPS) merupakan pembelajaran yang menjadikan siswa untuk mau berpikir, bekerja sama dengan orang lain, dan memberikan tanggung jawab untuk dapat mempresentasikan hasilnya di depan kelas.

Seperti model pembelajaran lainnya, model pembelajaran kooperatif tipe Think Pair Share (TPS) juga mempunyai kelebihan dan kekurangan. Ibrahim, dkk (2005: 35) mengemukakan bahwa Model pembelajaran kooperatif tipe Think Pair Share (TPS) memiliki kelebihan dan kekurangan. Kelebihannya antara lain : (1) Meningkatkan daya pikir siswa, (2) Memberikan lebih banyak waktu pada siswa untuk berfikir, (3) Mempermudah siswa dalam memahami konsep-konsep sulit karena siswa saling membantu dalam menyelesaikan masalah, dan (4) Pengawasan guru terhadap anggota kelompok lebih mudah karena hanya terdiri dari 2 orang.Selain beberapa kelebihan metode Think Pair Share (TPS) juga memiliki kelemahan antara lain: (1) Guru akan mengalami kesulitan dalam membimbing siswa yang membutuhkan perhatian lebih jika pada kelas yang besar, (2) Pemahaman tentang konsep dalam setiap pasangan 
akan berbeda sehingga akan dibutuhkan waktu tambahan untuk pelurusan konsep oleh guru dengan menunjukkan jawaban yang benar, dan (3) Lebih banyak waktu yang diperlukan untuk mempresentasikan hasil diskusi karena jumlah pasangan yang sangat besar.

\section{Teknik Mind Map}

Kemauan anak Sekolah Dasar dalam mencatat materi pelajaran masih sangat kurang. Selain itu kemampuan anak dalam mengingat juga materi yang ditulis juga terbatas. Hal ini tentu saja mempengaruhi pemahaman mereka terhadap materi. Untuk dapat menumbuhkan kemauan mencatat dan memudahkan mereka dalam mengingat materi pelajaran, maka diperlukan suatu teknik yang sesuai dengan istilah mind map. Teknik ini lebih dikenal dengan istilah pemetaan pikiran. Teknik ini merupakan cara termudah untuk menempatkan informasi ke dalam otak dan mengambil informasi ke luar dari otak.

Menurut Tony Buzan (dalam Sugiarto, 2012: 22) sebagai penemu teknik ini bahwa " A mind mapping is a powerfull graphic technique which provides a universal key to unlock the potential of the brain". Artinya peta pikiran adalah teknik pembuatan grafik yang menyediakan kunci universal untuk membuka potensi otak. Sebuah "peta pikiran" yang menggunakan unsur-unsur utama dari memori, asosiasi, lokasi, keistimewaan, dan yang mengarahkan semua keterampilan otak kiri dan otak kanan.

Sedangkan Windura (2013: 12) mendefinisikan mind map sebagai :

a. Sistem belajar dan berpikir yang menggunakan kedua belah otak

b. Sistem belajar dan berpikir yang menggunakan otak sesuai dengan cara kerja alaminya

c. Sistem belajar dan berpikir yang mengeluarkan seluruh potensi dan kapasitas otak penggunanya yang masih tersembunyi

d. Sistem belajar dan berpikir yang mencerminkan apa yang terjadi secara internal di dalam otak kita saat belajar dan berpikir

e. Sistem belajar dan berpikir yang mencerminkan secara visual apa yang terjadi pada otak saat anda belajar dan berpikir.

Sebelum menyusun Mind Map ada empat hal yang harus ada, antara lain: tema besar (terletak pada bagian tengah), subtema, urutan, dan garis hierarki.

Adapun langkah-langkah pembuatan mind map menurut Buzan (Doni, 2012: 15) adalah:

a.Sediakan kertas putih pada posisi landscape, letakkan pokok masalah di tengah kertas. b. Gunakan gambar, simbol atau foto untuk menggambarkan permasalahan pokok.

c.Hubungkan cabang-cabang utama dengan sub pokok masalah.

d. Buat garis lengkung seperti cabang pohon.

e.Gunakan satu kata kunci untuk setiap garis sub pokok bahasan.

f. Gunakan gambar atau simbol intuk mencari deskripsi pada sub pokok bahasan.

Adapun manfaat dari teknik mind map menurut Tony Buzan (dalam Sugiarto, 2012: 29) sebagai berikut: 1) meningkatkan kreativitas dan aktivitas individu maupun kelompok, 2) memudahkan otak memahami dan menyerap informasi dengan cepat, 3) meningkatkan daya ingat, 4) mengakomodasi berbagai sudut pandang terhadap suatu informasi, 5) memusatkan perhatian siswa, dan 6) mengaktifkan seluruh bagian otak.

Adapun kelemahan dari mind map, antara lain: 1) hanya siswa yang aktif yang terlibat, 2) Tidak sepenuhnya murid yang belajar, dan 3) Jumlah detail informasi tidak dapat dimasukkan

\section{METODE PENELITIAN}

Penelitian ini termasuk jenis penelitian pengembangan (developmental research). Penelitian pengembangan merupakan penelitian yang menghasilkan produk tertentu yang didasarkan pada analisis kebutuhan (Sugiyono, 2012: 297). Yang dihasilkan dalam produk ini adalah perangkat pembelajaran PKn melalui kooperatif tipe think pair share. Dalam penelitian ini dikembangkan perangkat pembelajaran dengan metode four D Models (4D).

Penelitian ini merupakan penelitian pengembangan, dengan model 4-D (four-d model) dari Thiagarajan, Semmei dan Semmel (1975:5). Model ini dipilih karena model lebih terperinci dan sistematis, sehingga memudahkan peneliti untuk melakukan penelitian. Selain itu model Four-D memiliki kelebihan lain dibandingkan dengan model lainnya, antara lain : (a) uraiannya lebih lengkap dan sistematis, (b) dalam pengembangannya melibatkan penilaian ahli, sehingga sebelum dilakukan ujicoba di lapangan perangkat pembelajaran telah dilakukan revisi berdasarkan penilaian, saran dan masukan para ahli atau validator yang memiliki kompetensi di bidang masing-masing.

Model 4-D terdiri dari tahap pendefinisian (define), tahap perancangan (design), tahap pengembangan (develop), dan tahap penyebaran (disseminate). Dalam rancangan penelitian ini, pengembangan perangkat pembelajaran hanya sampai pada tahap ketiga yaitu tahap 
pengembangan (develop). Dikarenakan keterbatasan biaya, tenaga, waktu dan kesempatan maka pendesiminasian tidak dilakukan dan hasil penelitian hanya diterapkan di tempat penelitian. Dalam penelitian ini, perangkat pembelajaran yang dikembangkan antara lain : Rencana RPP, MAS, LKS, dan THB.

Subjek uji coba ini adalah 6 siswa kelas IV Faqih Usman sebagai kelas ujicoba, sedang 16 siswa kelas IV Ar Fakhrudin SD Muhammadiyah Kota Madiun sebagai kelas implementasi pada semester II tahun pelajaran 2015/2016.

Berikut ini adalah rancangan penelitian pengembangan perangkat ini.

1. Tahap Pendefinisian (Define)

Tahap ini kegiatan terfokus pada analisis terhadap situasi yang dihadapi guru, karakteristik siswa, konsepkonsep yang akan diajarkan, dan diakhiri dengan tujuan pembelajaran. Tahap ini terdiri dari lima langkah yaitu analisis kebutuhan, analisis siswa, analisis konsep, analisis tugas, dan menentukan tujuan pembelajaran.

2. Tahap Perancangan (Design)

Tujuan tahap ini adalah untuk menyiapkan prototype perangkat pembelajaran. Tahap ini terdiri dari 3 langkah, yaitu (1) penyusunan tes acuan patokan, tes disusun berdasarkan hasil perumusan tujuan pembelajaran pembelajaran khusus. Tes ini merupakan suatu alat pengukur terjadinya perubahan tingkah laku pada diri siswa setelah kegiatan belajar mengajar; (2) pemilihan media yang sesuai tujuan, untuk menyampaikan materi pelajaran; (3) pemilihan format dan (4) validasi perangkat pembelajaran (draft 1)

3. Tahap Pengembangan (Develop)

Pada tahap ini, diawali dengan perangkat yang dikembangkan (Draft 1) mendapat penilaian, saran, masukan dan bimbingan dari para validator dan dosen pembimbing kemudian direvisi menjadi Revisi I (Draft 2) yang selanjutnya diujicobakan terhadap 6 siswa kelas IV Faqih Usman SD Muhammadiyah Kota Madiun. Analisis terhadap data yang terkumpul baik melalui lembar pengamatan, angket, dan THB pda kegiatan ujicoba untuk mendeskripsikan perlu tidaknya revisi berikutnya terhadap perangkat yang dikembangkan.

Selanjutnya jika perlu direvisi menjadi Revisi II (Draft 3) yang apabila perangkat tidak perlu direvisi, maka bisa langsung dengan implementasi.

Pada tahap pengembangan ini, hasil revisi perangkat pembelajaran siap untuk diuimplementasikan di kelas IV Ar Fakhrudin SD Muhammadiyah Kota Madiun dengan jumlah 16 siswa. Analisis, pada tahap ini data hasil implementasi dianalisis kembali untuk memperoleh gambaran lengkap tentang efektifitas perangkat pembelajaran yang telah dikembangkan dan dibuat dalam bentuk laporan.

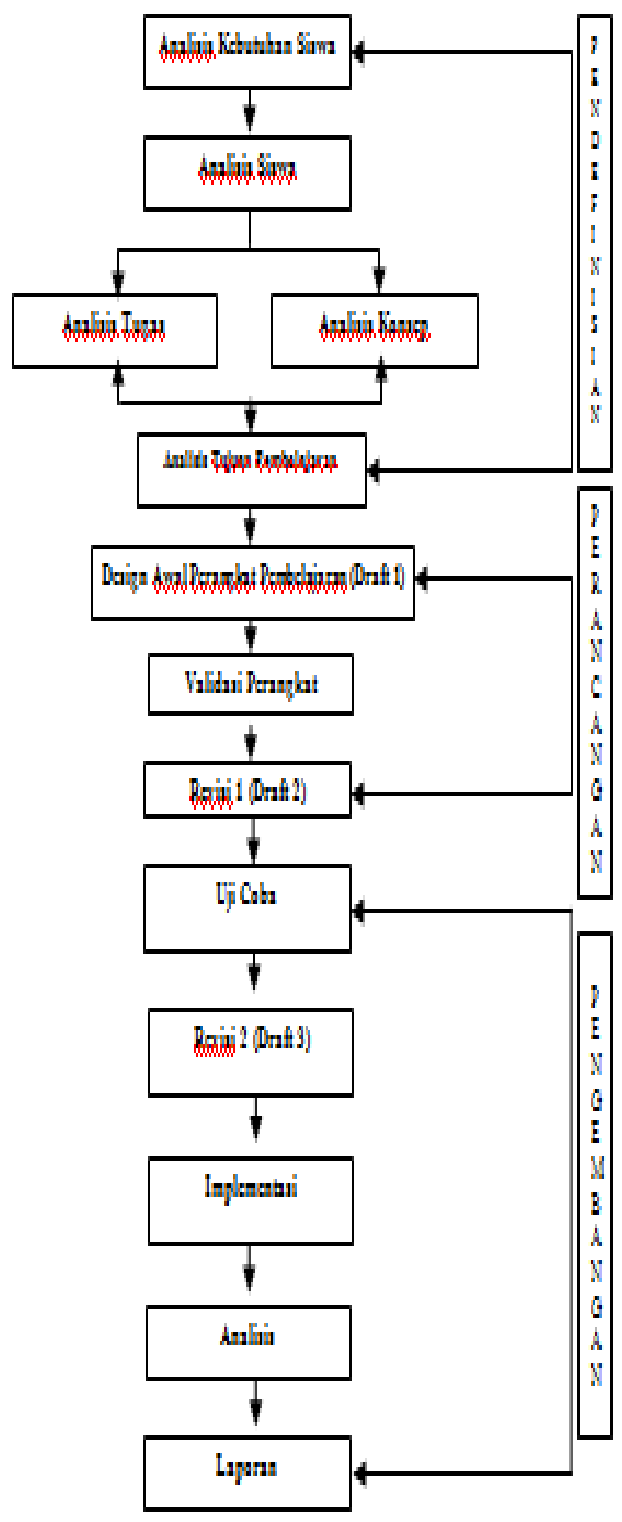

Bagan 1.

Tahap-Tahap Pengembangan

Sebelum diimplementasikan, perangkat terlebih dahulu diujicobakan guna mengetahui validitas, reliabilitas, gain skor, serta sensitivitas butir soal. Instrumen yang digunakan antara lain terdiri dari lembar vallidasi perangkat pembelajaran, angket keterbacaan, angket respon siswa, dan tes hasil belajar.

Data yang telah diperoleh kemudian dianalisis secara deskripsi kualitatif dan deskripsi kuantitatif. Adapun metode pengumpulan data yang digunakan antara lain validasi, observasi, angket dan tes. 


\section{HASIL DAN PEMBAHASAN}

\section{Kelayakan}

Berikut penilaian kelayakan perangkat pembelajaran ditunjukkan pada tabel berikut.

Tabel 3.

Rekap Kelayakan Perangkat Pembelajaran

\begin{tabular}{|c|c|c|c|c|}
\hline \multicolumn{4}{|c|}{ No. Perangkat Rerata Skor Reliabilitas } & Ket. \\
\hline 1 & RPP & $\begin{array}{l}\mathrm{V} 1=3,67 \\
\mathrm{~V} 2=3,47\end{array}$ & 0,98 & Baik \\
\hline 2 & MAS & $\begin{aligned} \mathrm{V} 1 & =3,75 \\
\mathrm{~V} 2 & =3,69\end{aligned}$ & 0,99 & Baik \\
\hline 3 & LKS & $\begin{array}{l}\mathrm{V} 1=3,5 \\
\mathrm{~V} 2=3,5\end{array}$ & 0,99 & Baik \\
\hline 4 & THB & $\begin{array}{l}\mathrm{V} 1=3,5 \\
\mathrm{~V} 2=3,3\end{array}$ & 0,99 & Baik \\
\hline
\end{tabular}

Dari hasil validasi perangkat skor RPP 3,57 dengan realibilitas 0,98. Hal ini memperlihatakan bahwa RPP dalam kategori baik, dapat digunakan dengan sedikit revisi . Sedangkan rata-rata skor MAS 3,72 dengan realibilitas 0,99 menunjukkan bahwa MAS sangat baik dan dapat digunakan tanpa revisi. Skor rata-rata LKS 3,5 dengan realibilitas 0,99, dalam kategori baik dan dapat digunakan dengan sedikit revisi. Pada perangkat pembelajaran berupa THB, skor rata-ratanya 3,4 dengan realibilitas 0,99 menunjukkan THB. Dari keseluruhan validasi diperoleh rata-rata skor 3,55 dengan realibilitas 0,99 dalam kategori baik dan dapat digunakan dengan sedikit revisi. Untuk keterbacaan MAS dan LKS melalui angket yang dibagikan \% siswa berpendapat isi MAS dan LKS sangat menarik, sangat baru, sangat mudah, dan sangat jelas.

\section{Kepraktisan}

Pada ujicoba yang dilaksanakan dalam kelas ujicoba sebanyak enam orang, sedangkan kegiatan implementasi dengan 16 siswa.

Berikut hasil pengamatan keterlaksanaan RPP ujicoba ditunjukkan pada tabel berikut.

Tabel 4.

Rekap Keterlaksanaan RPP Ujicoba

\begin{tabular}{cccccc}
\hline \multicolumn{2}{c}{ Pertemuan } & \multicolumn{2}{c}{ Pertemuan } & Rata- & Persentase \\
I & P2 & P1 & P2 & & \\
\cline { 1 - 4 } 60 & 60 & 62 & 61 & 61,5 & $90,4 \%$ \\
\hline
\end{tabular}

Pada tabel diatas menujukkan persentase keterlaksanaan RPP ujicoba adalah sebesar 90,4\%. Sedangkan pada implementasi dengan siswa sebanyak 16 siswa keterlaksanaan RPP sebesar 99,7\% seperti yang terlihat pada tabel berikut.
Tabel 5.

Rekap Keterlaksanaan RPP Implementasi

\begin{tabular}{cccccc}
\hline \multirow{2}{*}{$\begin{array}{c}\text { Pertemuan } \\
\text { I }\end{array}$} & \multicolumn{2}{c}{ Pertemuan } & \multirow{2}{c}{$\begin{array}{l}\text { Rata- } \\
\text { rata }\end{array}$} & Persentase \\
\cline { 1 - 4 } P1 & P2 & P1 & P2 & & \\
\hline 67 & 68 & 68 & 68 & 67,8 & $99,7 \%$ \\
\hline
\end{tabular}

Dengan demikian berdasarkan tabel 4 dan 5 perangkat pembelajaran ini dikatakan praktis karena hasil pengamatan keterlaksanaan pembelajaran baik pada kegiatan ujicoba maupun implementasi menunjukkan kategori baik. Hal ini artinya guru dapat melaksanakan pembelajaran sesuia dengan rencana.

\section{Keefektifan}

Perangkat pembelajaran dikatakan efektif jika (a) aktivitas siswa dalam kategori aktif, (b) respon siswa terhadap pembelajaran positif, dan (c) tes hasil belajar mencapai KKM. Adapun hasil penelitian ini tertera pada tabel berikut ini.

a) Aktivitas siswa

Berikut ini merupakan rata-rata penilaian pengamatan aktivitas siswa pada pertemuan dan pertemuan 2 .

Tabel 6.

Rekap Pengamatan Aktivitas Siswa Ujicoba

\begin{tabular}{cccccc}
\hline \multicolumn{2}{c}{ Pertemuan } & \multicolumn{2}{c}{ Pertemuan } & Rata- & Persentase \\
P1 & P2 & P1 & P2 & & \\
\cline { 1 - 4 } 61 & 65 & 68 & 75 & 67,3 & $88,5 \%$ \\
\hline
\end{tabular}

Menurut pengamatan kedua observer pada kegiatan ujicoba ini, keaktifan aktivitas siswa selalu mengalami peningkatan dari pertemuan I ke pertemuan II. Dari rata-rata pertemuan I sebesar 63 dan pertemuan II 71,6 dengan rata-rata 67,3 atau $88,5 \%$. Hal ini menunjukkan bahwa siswa dalam kategori sangat aktif.

Hal senada juga terjadi pada kegiatan implementasi. Dimana siswa lebih aktif pada pertemuan 2 daripada pertemuan 1 seperti pada tabel berikut.

\section{Tabel 7.}

Rekap Pengamatan Aktivitas Siswa Implementasi

\begin{tabular}{cccccc}
\hline \multirow{2}{*}{$\begin{array}{c}\text { Pertemuan } \\
\text { I }\end{array}$} & \multicolumn{2}{c}{$\begin{array}{c}\text { Pertemuan } \\
\text { II }\end{array}$} & $\begin{array}{l}\text { Rata- } \\
\text { rata }\end{array}$ & Persentase \\
\cline { 1 - 4 } P1 & P2 & P1 & P2 & & \\
\hline 71 & 74 & 74 & 76 & 73,8 & $97,1 \%$ \\
\hline
\end{tabular}

Pada pertemuan 1 keaktifan siswa hanya sebesar 95,4\%, sedangkan pada pertemuan 2 menjadi 98,7\%. Secara rata-rata berdasarkan pengamatan kedua pengamat, aktivitas siswa $97,1 \%$. 
Berdasarkan tabel 6 dan 7 menunjukkan siswa sangat aktif selama kegiatan pembelajaran baik pada kegiatan ujicoba ataupun implementasi.

b) Respon siswa terhadap pembelajaran

Keefektifan perangkat juga dilihat berdasarkan respon siswa. Pada kegiatan ujicoba, respon 1 siswa sebagai sesuatu yang kurang menarik pada LKS, sehingga siswa merespon positif sebesar $95,7 \%$ terhadap kegiatan pembelajaran yang mereka ikuti dan $93,7 \%$ siswa berminat mengikuti pembelajaran seperti ini lagi.

Respon siswa terhadap Materi Ajar Siswa (MAS) dan Lembar Kerja Siswa (LKS) adalah pada kegiatan implementasi sangat menarik, sangat baru, sangat mudah, dan sangat jelas. Respon seluruh siswa postif pada pembelajaran ini dengan 16 siswa merespon sebesar 100\% positif dan berminat mengikuti pembelajaran seperti ini lagi.

Berdasarkan dari hasil angket respon siswa pada kegiatan ujicoba dan implementasi menunjukkan bahwa respon siswa terhadap pembelajaran ini adalah positf.

c) Tes hasil belajar

Selain berdasarkan keaktifan dan respon siswa, untuk menguji keefektifan perangkat pembelajaran dengan melakukan tes. Adapun hasil tes belajar pada kegiatan ujicoba dan implementasi pada tabel berikut.

Tabel 8.

Tes Hasil Belajar Ujicoba

\begin{tabular}{ccccccc}
\hline No & $\begin{array}{c}\text { Nilai } \\
\text { Absen }\end{array}$ & $\mathrm{K}$ & $\begin{array}{c}\text { Nilai } \\
\text { Post- } \\
\text { test }\end{array}$ & $\mathrm{K}$ & $\mathrm{N}$ & $\mathrm{N}$ \\
test & & $\mathrm{K}$ & \\
1. & 70 & $\mathrm{~T}$ & 100 & $\mathrm{~T}$ & 1 & Tinggi \\
2. & 60 & $\mathrm{TT}$ & 80 & $\mathrm{~T}$ & 0,5 & Sedang \\
3. & 50 & $\mathrm{TT}$ & 70 & $\mathrm{~T}$ & 0,4 & Sedang \\
4. & 60 & $\mathrm{TT}$ & 80 & $\mathrm{~T}$ & 0,5 & Sedang \\
5. & 65 & $\mathrm{TT}$ & 90 & $\mathrm{~T}$ & 0,71 & Tinggi \\
6. & 60 & $\mathrm{TT}$ & 80 & $\mathrm{~T}$ & 0,5 & Sedang \\
\hline
\end{tabular}

Pada kegiatan ujicoba, pada nilai pre-test, hanya 1 siswa yang tuntas sehingga ketuntasan klasikal hanya $0,17 \%$. Sedangkan hasil nilai post-test semua siswa $100 \%$ tuntas mencapai nilai KKM dengan gain sebesar 0,6. Jika pada pre-test 60,8 berada di bawah KKM, sedangkan pada post-test hasilnya rata-rata 83,3 berada diatas KKM.

Sedangkan pada kegiatan implementasi, ditunjukkan pada tabel di bawah ini.
Tabel 9.

Tes Hasil Belajar Implementasi

\begin{tabular}{|c|c|c|c|c|c|c|}
\hline No & $\begin{array}{c}\text { Nilai } \\
\text { Pre- } \\
\text { test }\end{array}$ & $\mathrm{K}$ & $\begin{array}{c}\text { Nila } \\
\mathrm{i} \\
\text { Pos } \\
t- \\
\text { test }\end{array}$ & $\mathrm{K}$ & $\begin{array}{c}\mathrm{N} \\
\mathrm{Gai} \\
\mathrm{n}\end{array}$ & $\mathrm{K}$ \\
\hline 1. & 60 & TT & 95 & $\mathrm{~T}$ & 0,88 & Tinggi \\
\hline 2. & 55 & TT & 80 & $\mathrm{~T}$ & 0,78 & Tinggi \\
\hline 3. & 50 & TT & 75 & $\mathrm{~T}$ & 0,33 & Sedang \\
\hline 4. & 60 & TT & 80 & $\mathrm{~T}$ & 0,5 & Sedang \\
\hline 5. & 65 & TT & 95 & $\mathrm{~T}$ & 0,85 & Tinggi \\
\hline 6. & 60 & TT & 95 & $\mathrm{~T}$ & 0,85 & Tinggi \\
\hline 7. & 55 & TT & 85 & $\mathrm{~T}$ & 0,67 & Sedang \\
\hline 8. & 60 & TT & 90 & $\mathrm{~T}$ & 0,75 & Tinggi \\
\hline 9. & 70 & $\mathrm{~T}$ & 100 & $\mathrm{~T}$ & 1 & Tinggi \\
\hline 10. & 60 & TT & 85 & $\mathrm{~T}$ & 0,71 & Tinggi \\
\hline 11 & 55 & TT & 90 & $\mathrm{~T}$ & 0,78 & Tinggi \\
\hline 12 & 60 & TT & 95 & $\mathrm{~T}$ & 0,88 & Tinggi \\
\hline 13 & 35 & TT & 80 & $\mathrm{~T}$ & 0,69 & Sedang \\
\hline 14 & 55 & TT & 70 & $\mathrm{~T}$ & 0,33 & Sedang \\
\hline 15 & 50 & TT & 65 & $\begin{array}{l}\mathrm{T} \\
\mathrm{T}\end{array}$ & 0,3 & Sedang \\
\hline 16 & 60 & TT & 90 & $\mathrm{~T}$ & 0,75 & Tinggi \\
\hline $\begin{array}{l}\text { Rat } \\
\text { a- } \\
\text { rata }\end{array}$ & 56,8 & TT & 85 & $\mathrm{~T}$ & 0,65 & Sedang \\
\hline
\end{tabular}

Keterangan :

$\mathrm{T}:$ Tuntas

TT: Tidak Tuntas

Pada kegiatan implementasi, hasil pre-test hanya 1 siswa atau 6,25\% saja yang tuntas, dengan rata-rata 56,8. Sedangkan pada hasil belajar post-test setelah diterapkan pembelajaran kooperatif tipe think share pair ketuntasan klasikal 93,8\% dengan rata-rata 85 , dengan hanya satu siswa yang tidak tuntas, dengan gain sebesar 0,69 dalam kategori gain sedang.

Jadi dengan menggunakan perangkat pembelajaran kooperatif tipe Think Pair Share dengan menggunakan teknik mind map hasil THB siswa bisa mencapai KKM atau tuntas.

Adapun sensitivitas butir soal THB ditunjukkan pada tabel di berikut ini.

Tabel 10.

Sensitivitas Butir Soal

\begin{tabular}{|c|c|c|c|}
\hline \multirow{2}{*}{$\begin{array}{c}\text { No } \\
\text { Butir } \\
\text { Soal }\end{array}$} & \multicolumn{2}{|c|}{ Proporsi Soal } & \multirow{2}{*}{ Sensitivitas } \\
\hline & Pre-test & Post-test & \\
\hline 1. & 16 & 16 & 0 \\
\hline 2. & 7 & 14 & 0,5 \\
\hline 3. & 8 & 14 & 0,38 \\
\hline 4. & 8 & 11 & 0,19 \\
\hline
\end{tabular}




\begin{tabular}{cccc}
\hline 5. & 5 & 12 & 0,44 \\
6. & 12 & 14 & 0,13 \\
7. & 14 & 15 & 0,13 \\
8. & 13 & 16 & 0,19 \\
9. & 8 & 13 & 0,31 \\
10. & 6 & 10 & 0,25 \\
11. & 13 & 14 & 0,06 \\
12. & 14 & 14 & 0 \\
13. & 8 & 11 & 0,19 \\
14. & 8 & 11 & 0,19 \\
15. & 7 & 11 & 0,25 \\
16. & 7 & 12 & 0,31 \\
17. & 8 & 11 & 0,19 \\
18. & 16 & 16 & 0 \\
19. & 2 & 13 & 0,56 \\
20. & 10 & 14 & 0,24 \\
& Rata-rata & & 0,23 \\
\hline
\end{tabular}

Pada tabel 10 menunjukkan bahwa sensitivitas soal Tes Hasil Belajar (THB) rata-rata sebesar 0,23, berarti berkisar kurang dari satu. Hal ini menunjukkan bahwa rata-rata butir soal tidak sensitif.

\section{SIMPULAN DAN SARAN}

Berdasarkan analisis, pembahasan hasil, dan temuan penelitian, maka dapat disimpulkan bahwa perangkat pembelajaran kooperatif tipe TPS dengan menggunakan teknik mind map pada mata pelajaran PKN di kelas IV siswa SD ini layak untuk diimplementasikam karena telah memenuhi kriteria kelayakan, kepraktisan dan keefektifan.

Sesuai dengan simpulan dan temuan penelitian, dapat disampaikan saran-saran sebagai berikut:

1. Perangkat yang dikembangkan cocok diimplementasikan di SD

2. Guru dapat mengembangkan perangkat pembelajaran ini pada mata pelajaran dan materi lainnya.

3. Melalui pembelajaran kooperatif tipe TPS dapat menumbuhkan semangat siswa untuk berpikir, bekerja sama, menghormati, dan percaya diri.

4. Dengan menggunakan teknik mind map dapat meningkatkan kreativitas siswa

\section{DAFTRA PUSTAKA}

Aqib, Z. (2013). Model-Model, Media,dan Strategi Pembelajaran Kontekstual (Inovatif). Bandung: CV Yrama Widya.

BSNP. ( 2007). Panduan Penyusunan Kurikulum Tingkat satuan Pendidikan

Jenjang Pendidikan Dasar dan Menengah. Jakarta : Badan Sandar Nasional Pendidikan.
Ibrahim Muslimin, Rachmadiarti F, Nur M, Ismono. (2000). Pembelajaran Kooperatif. Surabaya: PSMS Unesa

Isjoni. (2009). Pembelajaran Kooperatif Meningkatkan Kecerdasan Antar Peserta Didik. Yogyakarta: Pustak Pelajar

Johnson, D.W., Johnson,R.T., \& Stanne, M.B. (2000). Cooperative Learning Methods. Jurnal International Learning.

Rusman. (2010). Model-model Pembelajaran. Jakarta: PT.Raja Grafindo Persada.

Sugiarto, Dino dan Puji Sumarsono. (2014). The Implementation of Think-Pair-Share Model to Improve Students' Ability in Reading Narrative Texts. International Journal of English and Education. ISSN: 2278-4012, Volume:3, Issue:3, July 2014. pp 206-216.

Sugiyono. (2010). Metode Penelitian Kuantitatif, Kualitatif dan $R \& D$. Bandung: Alfabeta.

Slavin, Robert E. (2005). Cooperative Learning Teori, Riset dan Praktik (Terjemahan daro Coopertive Learning: theory, research and practice). Bandung: Penerbit Nusa Media

Slavin, Robert E. (2011). Psikologi Pendidikan: Teori dan Praktik, Edisi Kesembilan, Jilid 1 (Terjemahan dari Educational Psychology:Theory and Practice, 9th ed). Jakarta: PT Indeks.

Suprijono, Agus. (2014). Cooperative Learning.Teori dan Aplikasi PAIKEM. Jakarta : Pustaka Belajar.

Swadarama, Doni. (2013). Mind Mapping dalam Kurikulum Pembelajaran. Jakarta: Gramedia.

Thiagarajan, S.Samuel, D.S dan Semmel, M.I. (1974) . Instructional Developmen for Training Teachers of Exceptional Children, A.Source Book, Blomngtn: Central for Innovation on teaching the handicapped.

Trianto. (2009). Mendesain Model Pembelajaran InovatifProgresif. Konsep, Landasan, dan Implementasinya pada Kurikulum Tingkat Satuan Pendidikan (KTSP). Jakarta: Kencana Prenada Media Group.

Windura, Sutanto. (2013). Mind Map. Jakarta: PT Elex Media Komputindo Kelompok Gramedia 